\title{
Knowledge and practice of infection prevention and control among healthcare workers: a COVID-19 pandemic experience
}

\author{
Rifat Yasmin, Huma Hussain ${ }^{1} \bowtie$, Syeda Turab Fatima Abidi ${ }^{1} \bowtie$, Syed Asim Ali Shah ${ }^{1} \bowtie$, \\ Tazaeen Hina Kazmi ${ }^{1} \bowtie$, Hina Hussain ${ }^{2} \bowtie$
}

Author affiliations:

1- Department of Medicine, POF Hospital, Quaid Avenue. Wah Cantt, Pakistan.

2- Department of Medicine, PAF Hospital, 14, Munir Road, Munir Chowk, Lahore Cantt, Pakistan.

Correspondence: Dr. Rifat Yasmin; E-mail: rifatyasmin99@yahoo.com; Phone: 03075384549

\section{Abstract}

Background: Coronavirus disease (COVID-19) is a global outbreak caused by novel SARS-CoV-2 (severe acute respiratory syndrome coronavirus 2). Study aims to evaluate knowledge and practices of healthcare workers (HCW) regarding infection prevention and control of corona virus disease

Material and methods: A cross sectional validation study was conducted. Study was conducted at department of Medicine, Pakistan Ordinance Factory Hospital, Wah Cantt. Study duration was 2 months (May 2020-June2020)A sample size of $217 \mathrm{HCW}$ was calculated using WHO calculator. HCW were selected through non probability sampling (consecutive). Ethical permission was taken and research consent was signed by each participant. SPSS version 24 was used for analysis purpose. Post stratification fissure exact and chi-square test was applied. We found $p$ value $\leq 0.05$ as statistically significant.

Results: Total 217 HCW were included in our study. Out of them, 85 (39.2\%) were male and 132 (60.8\%) were female in our study. Mean age of HCW was 34.5 $\pm 2.4 \mathrm{SD}$. In knowledge assessment majority of HCW had fair knowledge (46.5\%), followed by good (30\%) and poor knowledge (23.5\%) regarding corona virus associated infection control and prevention. In practice assessment, among all those, $38.2 \% \mathrm{HCW}$ showed better practices while $61.8 \%$ showed poor practices. Knowledge is significantly associated with virus transmission mode $(p=0.00)$, close contact $(p=$ $0.000)$, protection from COVID-19 in triage area $(p=0.000)$, wearing PPE $(p=0.000)$ etc.

Conclusion: Corona virus disease is a major challenge in resource limited countries. Healthcare workers showed relatively improved knowledge and practices regarding infection prevention and control in this COVID-19 Pandemic.

Key words: Corona virus disease, Healthcare workers, Infection Prevention and Control, Knowledge, Practices

Citation: Yasmin R, Hussain H, Abidi STF, Shah SAA, Kazmi TH, Hussain H. Knowledge and practice of infection prevention and control among healthcare workers: a COVID-19 pandemic experience. Anaesth pain intensive care 2020;24 (6):596-602; DOI 10.35975/apic.v24i6.1408

Received: 8 November 2020, Reviewed: 17 November 2020, Accepted: 19 November 2020

\section{Introduction}

Corona virus disease (COVID-19) is a global outbreak caused by novel SARS-CoV-2 (severe acute respiratory syndrome coronavirus 2$).{ }^{1}$ World Health Organization (WHO) reported that coronavirus is an emerging viral disease and serious public health issue as early as November 2019. First case of COVID-19 appeared in Wuhan (China) in December 2019. WHO declared coronavirus disease as 6th public health emergency in January 2020. ${ }^{2}$ COVID-19 is a third global outbreak affecting more than 209 countries including lower middle income countries like 
Pakistan. ${ }^{3}$ In Pakistan first case of coronavirus was confirmed by Ministry of Health on 26 February, 2020, in Karachi. According to Government of Pakistan, on 6th April 2020, there were 3277 confirmed COVID-19 cases. $^{4}$ Several healthcare workers (HCW) are working in this deadly scenario to bring back life and prevent number of confirmed cases in Pakistan.

COVID-19 emerged as infectious disease and present unique challenge to healthcare providers. Literature reported that threat to frontline responders in this pandemic is due to limited understanding of emerging pathogen transmission dynamics. Moreover, healthcare providers understanding and skills vary according to their knowledge and practices. During this pandemic, transmission of virus from patients to healthcare personal is very common in healthcare setting. ${ }^{5}$. Evidence exist that human to human transmission of corona virus is associated with contact of infectious respiratory mucosae droplets ${ }^{6}$. Center for disease control and prevention (CDC) reported infection prevention and control (IPC) guidelines regarding coronavirus disease depending upon virus transmissibility, viral shedding and other characteristics of virus ${ }^{7}$.

Adequate knowledge, positive attitude and safe practices are required for controlling this pandemic disease. Lack of knowledge among $\mathrm{HCW}$ is responsible for excessive spread of this COVID-19. A study conducted in Nepal showed that HCW had good to moderate knowledge $(82.15 \%)$ and practice (83.57\%). However, they reported a significant association between knowledge and practice scores regarding COVID-19 among $\mathrm{HCW}$ and their job description $(\mathrm{p}=0.000)^{8}$. Modi et al. reported that $45.4 \%$ respondents had awareness regarding mask application while $52.5 \%$ were aware of hand hygiene ${ }^{9}$. COVID-19 is a global threat, so its very important to improve knowledge and practices of $\mathrm{HCW}$ in Pakistan. Present study aims to evaluate knowledge and practices of HCW regarding IPC of corona virus disease.

\section{Methodology}

A cross-sectional study was conducted at our hospital for 2 months (May 2020-July 2020). A sample size of 217 was calculated using $82 \%^{8}$ frequency of good knowledge among $\mathrm{HCW}, 5 \%$ absolute precision, 95\% confidence interval using WHO calculator. Selection of HCW was done using non-probability consecutive sampling. Research approval was taken from ethical review committee of POF hospital. All participating $\mathrm{HCW}$ signed consent forms before participation in study. Inclusion criteria was based upon age $>18$ yrs, both genders, and employees of POF Hospital (doctors, nurses and other paramedical staff). HCW who were not willing to participate and those COVID19 positive were excluded. A structured questionnaire was used using European Center for Disease Control and Prevention (ECDC) guidelines, ${ }^{10}$ based upon demographic, knowledge (11 items) and practices (7items) questions were administered online and via mobile phone. We scored the positive answers as 1 and negative answers as 0 (more than 1 positive answers within one question were also scored 1). Scores 11-9 were categorized as good knowledge, 8-6 as fair knowledge and $<6$ as poor knowledge. Scores $>4$ in practice section were categorized as better practice and $<4$ as poor practice.

SPSS version 24 was used for analysis purpose. Nominal and categorical data were analyzed in terms of frequency and percentages, while descriptive statistics were presented in terms of mean and standard deviation. We controlled effect modifiers like age and gender using stratification process. Post stratification fissure exact and chi-square test were applied to observe association between knowledge, practices and other independent variables. Results with $\mathrm{p} \leq 0.05$ were considered statistically significant.

\section{Results}

A total of $217 \mathrm{HCW}$ were included in our study. There were $85(39.2 \%)$ males and $132(60.8 \%)$ females in our study. Mean age of HCW was $34.5 \pm 2.4$ yrs. 182 $(83.9 \%) \mathrm{HCW}$ were in age group 20-40 years, 33 $(15.2 \%)$ were in $40-60$ years age group and $2(0.9 \%)$ had age $>60$ years. There were $140(64.5 \%)$ doctors, $57(26.3 \%)$ nurses and $20(9.2 \%)$ paramedical staff. Designations of doctors included house officers 37 (17.1\%), postgraduate trainees / medical officers 51 (23.5\%), consultants / senior registrars / assistant / associate professors / professor $47(21.7 \%)$, nurses 56 (25.8\%), and paramedics $26(12 \%)$. The participants belonged to emergency $31(14.3 \%)$, critical care unit $30(13.8 \%)$, general ward $83(38.2 \%)$, COVID 
Ward/Corona desk 28 (12.9\%), diagnostic 12 (5.5\%) and others $33(15.2 \%)$. Infection control training had been taken by $120(55.3 \%) \mathrm{HCW}$ during the past three years; while $144(66.4 \%)$ of them were aware of donning and doffing technique regarding personal protective measure usage.

Knowledge regarding corona virus associated IPC is shown in Figure 1, and grading of practices regarding IPC of COVID-19 is shown in Figure 2.

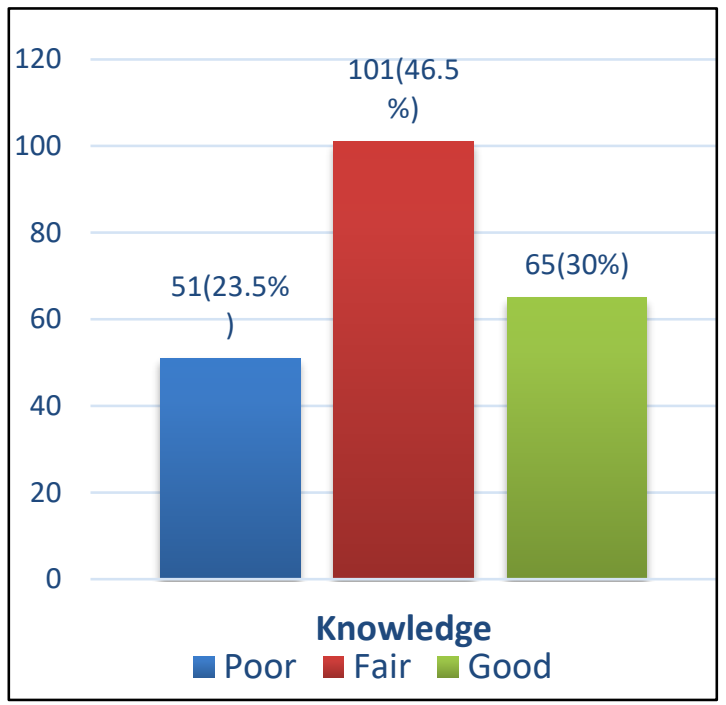

Figure 1: HCW Knowledge state

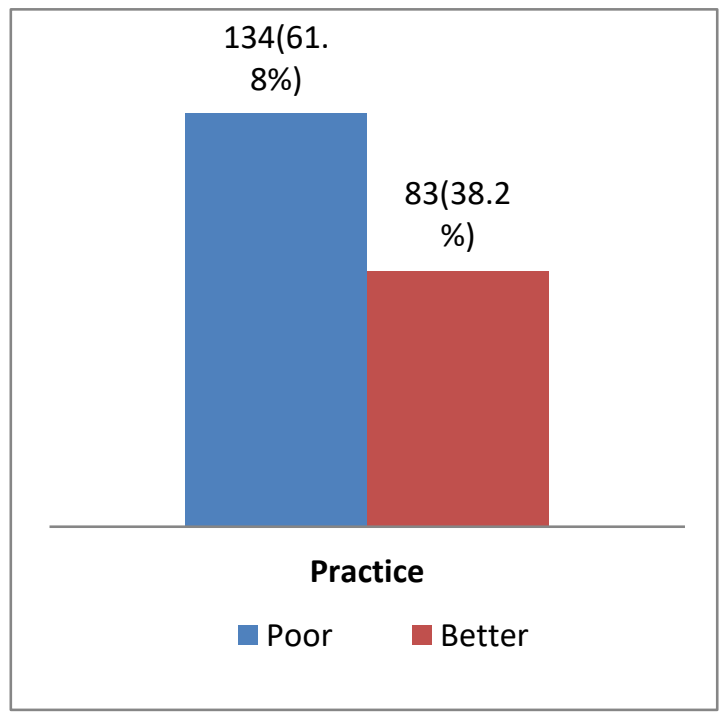

Figure 2: HCW practice state

Majority of HCW who answered correct regarding SARS-CoV-2 virus transmission had fair knowledge as compared to those who answered wrong ( $31.8 \%$ vs $14.7 \%, p=0.00)$. Majority of HCW who answered correct regarding close contact had fair knowledge regarding IPC of COVID-19 as compared to those who answered wrong $(p=0.000)$. Majority of HCW had good knowledge regarding protection from COVID-19 in triage area followed by fair and poor knowledge $(27.2 \%, 22.1 \%$ ad $4.1 \%$ respectively, $\mathrm{p}=$ $0.000)$. Majority of $\mathrm{HCW}$ fairly know about wearing PPE for transportation of COVID-19 patients ( $\mathrm{p}=$ 0.000 ). Preferred method of hand hygiene and most effective method for prevention of COVID-19 is insignificantly associated with knowledge of $\mathrm{HCW}$ ( $>0.05)$ as shown in Table 1.

Out of all, 15 (6.9\%) had good knowledge regarding nasopharyngeal swab taking of COVID-19 patients in closed room $(p=0.007)$. HCW had good knowledge regarding COVID-19 patient placement in closed room $(p=0.000)$, fair knowledge regarding aerosol generating procedure in healthcare facilities $(\mathrm{p}=$ 0.000 ) and had fair knowledge regarding aerosol generating procedure performance in airborne isolation room $(\mathrm{p}=0.000)$ as shown in Table 1.

Out of all, 31.3\% HCW showed better hand hygiene practice $(\mathrm{p}=0.000), 44(20.3 \%)$ always removed PPE carefully ( $\mathrm{p}=0.000), 35(16.1 \%)$ covered their mouth during cough and sneezing with tissue or handkerchief $(p=0.002), 30(13.8 \%)$ maintained quarantine with their family members $(\mathrm{p}=0.01)$ and $83(38.2 \%)$ avoided overcrowding in emergency $(\mathrm{p}=0.000)$, $22.1 \%$ showed better practice of removing mask correctly $(\mathrm{p}=0.000)$, and $31(14.3 \%)$ were practicing social distance at least 1 meter as shown in Table 2. Age and gender showed insignificant association with knowledge and practices $(\mathrm{p}>0.05)$.

Among all the HCW, 18.9\% doctors reported good knowledge, $8.3 \%$ nurses showed good knowledge and $2.8 \%$ paramedical staff had good knowledge $(\mathrm{p}=$ 0.03). Among all the HCW, $26.3 \%$ doctors, $9.7 \%$ nurses and $2.3 \%$ paramedical staff showed better practices $(p=0.01)$ as shown in Table 3 . We found good knowledge among HCW of COVID-19 ward/corona desk, followed by general ward (medicine, surgery \& allied), critical care unit and emergency department $(\mathrm{p}=0.000)$. Better practices were reported by Corona and general wards HCW followed by critical care units, emergency department and diagnostics $(\mathrm{p}=0.000)$. 
Table 1: Knowledge level in HCW regarding IPC of COVID-19. Data given as n (\%).

\begin{tabular}{|c|c|c|c|c|c|c|c|}
\hline \multirow{2}{*}{ No. } & \multirow{2}{*}{ Questions } & \multirow{2}{*}{$\begin{array}{l}\text { Wrong / } \\
\text { Correct }\end{array}$} & \multicolumn{3}{|c|}{ Knowledge } & \multirow{2}{*}{ Total } & \multirow{2}{*}{$\begin{array}{c}\text { p- } \\
\text { value }\end{array}$} \\
\hline & & & Poor & fair & good & & \\
\hline \multirow[t]{2}{*}{1} & \multirow{2}{*}{$\begin{array}{l}\text { Mode of SARS CoV-2 } \\
\text { virus transmission }\end{array}$} & Wrong & $21(9.7)$ & $32(14.7)$ & $10(4.6)$ & $63(29)$ & \multirow{2}{*}{0.00} \\
\hline & & Correct & $30(13.8)$ & $69(31.8)$ & $55(25.3)$ & $154(71)$ & \\
\hline \multirow[t]{2}{*}{2} & \multirow{2}{*}{$\begin{array}{l}\text { Definition of close } \\
\text { contact }\end{array}$} & Wrong & $45(20.7)$ & 77 (35.5) & $24(11.1)$ & $146(67.3)$ & \multirow{2}{*}{0.000} \\
\hline & & Correct & $6(2.8)$ & 24 (11.1) & 41 (18.9) & $71(32.7)$ & \\
\hline \multirow[t]{2}{*}{3} & \multirow{2}{*}{$\begin{array}{l}\text { Preferred method of } \\
\text { hand hygiene }\end{array}$} & Wrong & $12(5.5)$ & $22(10.1)$ & $2(5.5)$ & $46(21.2)$ & \multirow{2}{*}{0.787} \\
\hline & & Correct & $39(18)$ & 79 (36.4) & $53(24.4)$ & $171(78.8)$ & \\
\hline \multirow[t]{2}{*}{4} & \multirow{2}{*}{$\begin{array}{l}\text { Most effective method } \\
\text { for prevention of COVID } \\
-19\end{array}$} & Wrong & $3(1.4)$ & $3(1.4)$ & $0(0)$ & $6(2.8)$ & \multirow[b]{2}{*}{0.157} \\
\hline & & Correct & $48(22.1)$ & 98 (45.2) & $65(30)$ & $211(97.2)$ & \\
\hline \multirow[t]{2}{*}{5} & \multirow{2}{*}{$\begin{array}{l}\text { Measures for protection } \\
\text { Of HCW from COVID-19 } \\
\text { in triage area }\end{array}$} & Wrong & $42(19.4)$ & $53(24.4)$ & $6(2.8)$ & $101(46.5)$ & \multirow[b]{2}{*}{0.000} \\
\hline & & Correct & $9(4.1)$ & $48(22.1)$ & $59(27.2)$ & $116(53.5)$ & \\
\hline \multirow[t]{2}{*}{6} & \multirow{2}{*}{$\begin{array}{l}\text { Type of PPE worn by } \\
\text { HCW for transportation } \\
\text { of COVID-19 Patient }\end{array}$} & Wrong & 30 (13.8) & $15(6.9)$ & $3(1.4)$ & $48(22.1)$ & \multirow{2}{*}{0.000} \\
\hline & & Correct & $21(9.7)$ & 86 (39.6) & $62(28.6)$ & $169(77.9)$ & \\
\hline \multirow[t]{2}{*}{7} & \multirow{2}{*}{$\begin{array}{l}\text { PPE worn by HCW for } \\
\text { nasopharyngeal swab }\end{array}$} & Wrong & $30(13.8)$ & $9(4.1)$ & $2(0.9)$ & $41(18.9)$ & \multirow{2}{*}{0.000} \\
\hline & & Correct & $21(9.7)$ & $92(42.4)$ & $63(29)$ & $176(81.1)$ & \\
\hline \multirow[t]{2}{*}{8} & \multirow{2}{*}{$\begin{array}{l}\text { Nasopharyngeal swab of } \\
\text { COVID-19 patients } \\
\text { taken in closed room }\end{array}$} & Wrong & $48(22.1)$ & $92(42.4)$ & $50(23)$ & $190(87.6)$ & \multirow[b]{2}{*}{0.007} \\
\hline & & Correct & $3(1.4)$ & $9(4.1)$ & $15(6.9)$ & $27(12.4)$ & \\
\hline \multirow[t]{2}{*}{9} & \multirow{2}{*}{$\begin{array}{l}\text { COVID-19 confirmed } \\
\text { patients should be } \\
\text { placed in closed room }\end{array}$} & Wrong & $33(15.2)$ & $93(42.9)$ & $45(20.7)$ & $171(78.8)$ & \multirow[b]{2}{*}{0.000} \\
\hline & & Correct & $18(8.3)$ & $8(3.7)$ & $20(9.2)$ & $46(21.2)$ & \\
\hline 10 & Aerosol generating & Wrong & $21(9.7)$ & $9(4.1)$ & $3(1.4)$ & $33(15.2)$ & \\
\hline & $\begin{array}{l}\text { procedures in healthcare } \\
\text { facilities }\end{array}$ & Correct & $30(13.8)$ & $92(42.4)$ & $62(28.6)$ & $184(84.8)$ & 0.000 \\
\hline 11 & Aerosol generating & Wrong & $21(9.7)$ & $15(6.9)$ & $0(0)$ & $36(16.6)$ & \\
\hline & $\begin{array}{l}\text { procedures in COVID-19 } \\
\text { patients should be } \\
\text { performed in airborne } \\
\text { isolation room }\end{array}$ & Correct & $30(13.8)$ & $86(39.6)$ & $65(30)$ & $181(83.4)$ & 0.000 \\
\hline
\end{tabular}

Table 2: Grading of practices of HCW regarding IPC in COVID -19. Data given as $\mathbf{n}(\%)$.

\begin{tabular}{|c|c|c|c|c|c|c|}
\hline \multirow{2}{*}{ No. } & \multirow{2}{*}{ Practices } & \multirow{2}{*}{ Yes/No } & \multicolumn{2}{|c|}{ Grade } & \multirow{2}{*}{ Total } & \multirow{2}{*}{$\begin{array}{c}\text { p- } \\
\text { value }\end{array}$} \\
\hline & & & Poor & Better & & \\
\hline \multirow{2}{*}{1} & \multirow{2}{*}{ Hand hygiene } & No & $75(34.6)$ & $15(6.9)$ & $90(41.5)$ & \multirow{2}{*}{0.000} \\
\hline & & Yes & $59(27.2)$ & $68(31.3)$ & $127(58.5)$ & \\
\hline \multirow{2}{*}{2} & \multirow{2}{*}{ Always remove PPE carefully } & No & $119(54.8)$ & $39(18)$ & $158(72.8)$ & \multirow{2}{*}{0.000} \\
\hline & & Yes & $15(6.9)$ & $44(20.3)$ & $59(27.2)$ & \\
\hline \multirow[b]{2}{*}{3} & \multirow{2}{*}{$\begin{array}{l}\text { While coughing and sneezing do } \\
\text { you cover your mouth with elbow, } \\
\text { tissue or handkerchief }\end{array}$} & No & $105(48.4)$ & $48(22.1)$ & $153(70.5)$ & \multirow[b]{2}{*}{0.002} \\
\hline & & Yes & $29(13.4)$ & $35(16.1)$ & $64(29.5)$ & \\
\hline \multirow{2}{*}{4} & \multirow{2}{*}{ Maintain Quarantine with Family } & No & $107(49.3)$ & $53(24.4)$ & $160(73.7)$ & \multirow{2}{*}{0.01} \\
\hline & & Yes & $27(12.4)$ & $30(13.8)$ & $57(26.3)$ & \\
\hline 5 & Avoid overcrowding in emergency & No & $48(22.1)$ & $0(0)$ & $48(22.1)$ & 0.000 \\
\hline
\end{tabular}




\begin{tabular}{|c|c|c|c|c|c|c|}
\hline & & Yes & 86 (39.6) & 83 (38.2) & 169 (77.9) & \\
\hline \multirow{2}{*}{6} & \multirow{2}{*}{ Do you remove mask correct } & No & $109(50.2)$ & 35 (16.1) & $144(66.4)$ & \multirow{2}{*}{0.000} \\
\hline & & Yes & $25(11.5)$ & $48(22.1)$ & $73(33.6)$ & \\
\hline \multirow{2}{*}{7} & \multirow{2}{*}{$\begin{array}{l}\text { Are you practicing social } \\
\text { distancing of at least } 1 \text { meter }\end{array}$} & No & $134(61.8)$ & $52(24)$ & $186(85.7)$ & \multirow{2}{*}{0.000} \\
\hline & & Yes & $0(0)$ & $31(14.3)$ & $31(14.3)$ & \\
\hline
\end{tabular}

Table 3: Association between occupation, knowledge and practices of HCW. Data given as $n$ (\%).

\begin{tabular}{|c|c|c|c|c|c|c|}
\hline Parameter & Grade & Doctors & Nurses & $\begin{array}{c}\text { Paramedical } \\
\text { staff }\end{array}$ & Total & p-value \\
\hline \multirow{3}{*}{ Knowledge } & Poor & $36(16.6)$ & $11(5.1)$ & $4(1.8)$ & $51(23.5)$ & \multirow{3}{*}{0.03} \\
\hline & Fair & $63(29)$ & $28(12.9)$ & $10(4.6)$ & $101(46.5)$ & \\
\hline & Good & $41(18.9)$ & $18(8.3)$ & $6(2.8)$ & $65(30)$ & \\
\hline \multirow{3}{*}{ Practice } & Poor & $83(38.2)$ & $36(16.6)$ & $15(6.9)$ & $134(61.8)$ & \multirow{3}{*}{0.01} \\
\hline & Better & $57(26.3)$ & $21(9.7)$ & $5(2.3)$ & $83(38.2)$ & \\
\hline & Total & $140(64.5)$ & 57 (26.3) & $20(9.2)$ & $217(100)$ & \\
\hline
\end{tabular}

\section{Discussion}

Corona virus disease is an emerging global health challenge leading towards ever-increasing mortality. ${ }^{11}$ HCW are more prone to acquire COVID-19 as compared to general population. ${ }^{12}$ So it is very important for $\mathrm{HCW}$ to understand clinical manifestation of disease, differential diagnosis, prevention, and treatment strategies. There is a need to improve their knowledge level and practices regarding COVID-19.

In the present study, majority of $\mathrm{HCW}$ had fair knowledge $(46.5 \%)$ regarding IPC of corona virus. Olum et al. reported that mean knowledge scores among HCW regarding COVID-19 were $82.4 \%$ in Sub-Saharan Africa and Uganda. ${ }^{13}$ Huynh et al. ${ }^{14}$ reported that mean knowledge scores were $8.17 \pm 1.3$, while majority of HCW had appropriate knowledge regarding mode of transmission, isolation period and protective distance similar to our study. In our study $25.3 \% \mathrm{HCW}$ had good knowledge regarding mode of transmission. However, Ashafi \& Cheng reported in a South Korean study that HCW had poor knowledge regarding transmission of corona virus. ${ }^{15,16}$

In ours study, $38.2 \% \mathrm{HCW}$ showed better practices regarding infection control and prevention of COVID19. Zhang et al. reported that $89.7 \%$ of healthcare professionals followed correct practices; however, their practices were associated with working time, experience and other hospital based factors. ${ }^{17}$ Murthy et al. ${ }^{18}$ reported that $\mathrm{HCW}$ are less likely to maintain quarantine with family similar to our study. In our study, $31.3 \%$ HCW showed better practices regarding hand hygiene while Jiang et al. reported that overworking nurses were less likely to wash hands as compared to less working nurses. ${ }^{19}$ Another similar study reported that majority of health workers were participating in training sessions. ${ }^{20}$ However, in our study only $16.1 \%$ showed better practice of training session. We found $38.2 \%$ of $\mathrm{HCW}$ avoided overcrowding in emergency department, while Radanovich et al. reported that $\mathrm{HCW}$ found overcrowding as major barrier for infection control and prevention during corona pandemic. ${ }^{21}$

\section{Limitations}

Online questionnaire based survey limits generalization of any study due to recall bias.

\section{Strengths}

It's a unique study in resource limited country like Pakistan where corona virus is considered as a myth more than a disease. As second peak of corona virus is currently in full swing, this paper might help to understand knowledge level of HCW, so that necessary steps are taken for further improvements by the authorities concerned. 


\section{Conclusion}

Corona virus disease is a major challenge in resource limited countries. Healthcare workers in our hospital showed relatively improved knowledge and good practices regarding infection prevention and control in COVID-19 pandemic. We recommend continual professional educational sessions for healthcare workers to further improve their knowledge and practices regarding corona virus disease.

\section{Conflict of interests}

None declared by the authors.

\section{Authors' contribution}

All authors took equal part in the conduct of this study and preparation of the manuscript.

\section{References}

1. Yin $Y$, Wunderink RG. MERS, SARS and other coronaviruses as causes of pneumonia. Respirology. 2018;23 2) (2):130-137. [PubMed] DOI: 10.1111/resp.13196

2. Li Q, Guan X, Wu P, Wang X, Zhou L, Tong $Y$ et al. Early Transmission Dynamics in Wuhan, China, of Novel Coronavirus-Infected Pneumonia. N Engl J $\begin{array}{lll}\text { Med. 2020;382 (13):1199-1207. [PubMed] } & \end{array}$ DOI: 10.1056/NEJMoa2001316

3. Lai C, Shih T, Ko W, Tang H, Hsueh P. Severe acute respiratory syndrome coronavirus 2 (SARS-CoV-2) and coronavirus disease-2019 (COVID-19): The epidemic and the challenges. Int J Antimicrob Agents. 2020;55 (3):105924.

[PubMed]

\section{DOI: 10.1016/i.jiantimicag.2020.105924}

4. Waris A, Atta UK, Ali M, Asmat A, Baset A. COVID-19 outbreak: current scenario of Pakistan. New Microbes New Infect. 2020 Apr 14:35:100681. [PubMed] DOI: 10.1016/.inmni.2020.100681

5. Backer J, Klinkenberg D, Wallinga J. Incubation period of 2019 novel coronavirus (2019-nCoV) infections among travellers from Wuhan, China, 20-28 January 2020. Euro Surveill. 2020;25 (5):123-5. [PubMed] DOI: 10.2807/1560-7917.ES.2020.25.5.2000062

6. Hoffman SJ, Silverberg SL. Delays in Global Disease Outbreak Responses: Lessons from H1N1, Ebola, and Zika. Am J Public Health. 2018;108 (3):329333. [PubMed] DOI: $10.2105 /$ AJPH.2017.304245
7. Center for Disease Control and Prevention. Corona virus 2019. https://www.cdc.gov/coronavirus/2019ncov/hcp/infection-control-recommendations.html

8. Nepal R, Sapkota K, Adhikari K, Paudel P, Adhikari B, Paudyal $\mathrm{N}$, et al. Knowledge, attitude and practice regarding COVID-19 among healthcare workers in Chitwan, Nepal.2020;2(1):12-15. DOI: https://doi.org/10.3126/jcmc.v10i3.32064

9. Modi PD, Nair G, Uppe A, Modi J, Tuppekar B, Gharpure SA, et al. COVID-19 Awareness Among Healthcare Students and Professionals in Mumbai Metropolitan Region: A Questionnaire-Based Survey. $\begin{array}{lllll}\text { Cureus } & 12 & \text { (4): } \quad \text { e7514 [PubMed] }\end{array}$ DOI: $10.7759 /$ cureus. 7514

10. European Centre for Disease Prevention and Control (ECDC). Contact tracing: Public health management of persons, including healthcare workers, having had contact with COVID-19 cases in the European Union second update [Internet]. [updated 9 April 2020]. Available from: https://www.ecdc.europa.eu/en/COVID19-contacttracing-public-health-management

11. Lai C, Shih T, Ko W, Tang H, Hsueh P. Severe acute respiratory syndrome coronavirus 2 (SARS-CoV-2) and coronavirus disease-2019 (COVID-19): The epidemic and the challenges. Int J Antimicrob Agents. 2020;55 (3):105924.

[PubMed] DOI: $\underline{\text { 10.1016/j.jijantimicag.2020.105924 }}$

12. Backer J, Klinkenberg D, Wallinga J. Incubation period of 2019 novel coronavirus (2019-nCoV) infections among travellers from Wuhan, China, 20-28 January 2020. Euro Surveill. 2020;25 (5):23-6. [PubMed] DOI: $10.2807 / 1560-7917 . E S .2020 .25 .5 .2000062$

13. Olum R., Chekwech G, Wekha G, Nassozi R.D, Bongomin F. Coronavirus Disease-2019: Knowledge, Attitude, and Practices of Health Care Workers at Makerere University Teaching Hospitals, Uganda. Frontier in public health. 2020; 8 (1):181-5. [PubMed] doi: 10.3389/fpubh.2020.00181

14. Huynh G, Nguyen HNT, Tran KV, Vo NK, Vo TV, Pham AL. Knowledge and attitude toward COVID19 among healthcare workers at District 2 Hospital, Ho Chi Minh City A. Asian Pac J Trop Med. 2020;13 (6):260-5 [Free full text] DOI: 10.4103/19957645.280396

15. Alsahafi J.A, Cheng C.A. Knowledge, Attitudes and Behaviours of Healthcare Workers in the Kingdom of Saudi Arabia to MERS Coronavirus and Other Emerging Infectious Diseases. Int. J. Environ. Res. 
Public Health 2016,13 (12), $1214 . \quad$ [PubMed] DOI: $10.3390 /$ ijerph13121214

16. Ng K, Poon BH, Kiat Puar TH, Shan Quah JL, Loh WJ, Wong YJ, et al. COVID-19 and the Risk to Health Care Workers: A Case Report. Anal. Int. Med. 2020;2 (1):128. [PubMed] DOI: 10.7326/L20-0175

17. Zhang M, Zhou M, Tang F, Wang Y, Nie H, Zhang L, You G. Knowledge, attitude, and practice regarding COVID-19among healthcare workers in Henan, China. journal of Hospital Infection. 2020;105 (2):183-7. [PubMed] DOI: 10.1016/j.jhin.2020.04.012

18. Gan WH, Lim JW, Koh D. Preventing Intra-hospital Infection and Transmission of Coronavirus Disease 2019 in Health-care Workers. Saf Health Work. 2020 Jun;11(2):241-243.

[PubMed] DOI: $10.1016 /$ j.shaw.2020.03.001
19. Jiang L, Ng IHL, Hou Y, Li D, Tan LWL, Ho HJA, Chen Ml. . Infectious disease transmission: survey of contacts between hospital-based healthcare workers and working adults from the general population. J Hosp. Inf. 2018;98 (4):404-11.

[PubMed] DOI: 10.1016/j.jhin.2017.10.020

20. Wang J, Zhou M, Liu F. Exploring the reasons for healthcare workers infected with novel coronavirus disease 2019 (COVID-19) in China.J Hosp Infect 2020;105:100-101. [PubMed] DOI: 10.1016/j.jhin.2020.03.002

21. Radonovich LJ Jr, Simberkoff MS, Bessesen MT, Brown AC, Cummings DAT, Gaydos CA, et al. N95 respirators vs medical masks for preventing influenza among health care personnel: a randomized clinical trial. JAMA 2019;322:824-833.

[PubMed] DOI: $10.1001 / \mathrm{jama} .2019 .11645$ 